\title{
Ethnobotany of traditional medicinal plants used by Dayak Desa Community in Sintang, West Kalimantan, Indonesia
}

\author{
MARKUS IYUS SUPIANDI ${ }^{1, \vartheta}$, SUSRIYATI MAHANAL ${ }^{2, \nu},{ }^{,}$, SITI ZUBAIDAH ${ }^{2}$, HENDRIKUS JULUNG ${ }^{1}$, \\ BENEDIKTUS EGE \\ ${ }^{1}$ Program of Biology Education, STKIP Persada Khatulistiwa Sintang. Jl. Pertamina Km 4, Sengkuang, Sintang, West Kalimantan, Indonesia. \\ Tel./fax. +62-565-21135, "email: msupiandi@gmail.com \\ ${ }^{2}$ Program of Biology Education, Universitas Negeri Malang. J1. Semarang No. 5, Malang 65145, East Java, Indonesia. Tel.: +62-341-567382, \\ "email: susriyati.mahanal.fmipa@um.ac.id
}

Manuscript received: 6 February 2019. Revision accepted: 19 April 2019

\begin{abstract}
Supiandi MI, Mahanal S, Zubaidah S, Julung H, Ege B. 2019. Ethnobotany of traditional medicinal plants used by Dayak Desa Community in Sintang, West Kalimantan, Indonesia. Biodiversitas 20: 1264-1270. Dayak Desa community has a long history of using medicinal plants as one of the methods to overcome health problems. Along with the advancement of science, the influx of foreign cultures and environmental degradation, traditional knowledge about medicinal plants and their utilization are only owned by the old generation. This study, therefore, aimed to identify medicinal plants used by Dayak Desa community who lives in Pakak Village. To collect information from the community, a survey was conducted in June 2017. Snowball sampling method was utilized to select 6 informants from whom information related to the plants' local names, the used parts of the plants, and the ways of managing and using the plants for curing illnesses was obtained through structured interviews. Data analysis was qualitative and quantitative. The results show that 25 species of medicinal plants from 9 families. The most widely used part of the plants is the leaves. The people in the community boil the leaves and drink the extract. Based on the results of the ICS analysis, the plant's value ranged from 1 to 24 . The highest value was observed in keladi (Colocasia esculenta L.) and the lowest value was found in kayu kenanga (Canangium odoratum Baill)
\end{abstract}

Keywords: Dayak ethnic groups, Dayak Desa, ethnobotany, medicinal plants, traditional knowledge

\section{INTRODUCTION}

West Kalimantan is the fourth largest province in Indonesia of which Dayak ethnic groups dominate population. One of the sub-ethnics who lives in Sintang District of West Kalimantan is called Dayak Desa community. Dayak ethnic groups possess cultures, traditions, and biodiversity richness which offer unique opportunities for ethnobotany researchers to explore it. Dayak Desa community has a long history of traditional/herbal medicine practices that also relate to cultural values and beliefs. The traditional treatment of Dayak Desa community deals with types of medical care and practices based on indigenous knowledge by utilizing plants to treat various diseases (Setyawan 2010; Roslinda 2016). Traditional medicine provides much information about the use of many plants or parts of the plants as medicine.

The utilization of potentially medicinal plants by Dayak Desa community encountered various problems as follows: (i) only a few parents deliver the information about the types of medicinal plants and techniques of their use to their children (Julung et al. 2018); (ii) modern medicine or western health treatments are gradually taking out traditional medicine (Kustiawan 2007); and (iii) forest degradation in West Kalimantan increases every year due to the increasing land clearance for the development of industrial forest plantations, oil palm plantations, illegal logging and shifting cultivation threatening the conservation of germplasm, and endemic species, especially plants that have potential as medicinal plants (Setyawan 2010). In addition, knowledge about the use of medicinal plants starts to vanish because it is only passed from generation to generation orally and has remained unwritten (Kaido et al. 1997).

Issues related to the potential use of medicinal plants can threaten the sustainability of traditional knowledge, biodiversity and even the germplasm of the plants. In fact, according to Setyawan (2010), traditional knowledge is very useful to preserve biodiversity in Borneo forests; thus, it needs to be maintained (Yusro et al. 2014). Bennet (2005) states that traditional knowledge needs to be documented in order that forest resources can be well managed. Therefore, before disseminating the knowledge, the local community should recognize the characteristics and the benefits of the plants (Hamzari 2008).

There has been much effort put into biodiversity conservation, such as the inventory of the utilization, cultivation, and preservation of plants through ethnobotany. Ethnobotany is the study of the utilitarian relationships between humans and their surrounding vegetation, including drug use (Albuquerque et al. 2006). Ethnobotany does not only cover botany taxonomy data, but also the botanical knowledge that is regional. It can be in the form of interpretation and association review which studies mutual relationships between humans and plants, and 
related to the utilization of the plant in sustaining culture and natural resources (Darmono 2007). Ethnobotany studies the interaction between plants and humans. It puts a particular emphasis on culture and its traditional use (Martin 1995; Cotton 1996; Balick and Cox 1996; Pie and Xiu 2002; Choudhary et al. 2008). Ethnobotany has evolved into a specific discipline that focuses on the relationships between humans and plants in a multidisciplinary way, not only with the collection, documentation, and utilization by local communities but also ecology, economics, pharmacology, public health and other disciplines (Balick and Cox 1996).

Today, ethnobotany has become increasingly popular in the development of health and conservation programs around the world. Ethnobotany is essential for biodiversity conservation (Martin 1995; Cunningham 2001; Alexiades 2003; Aryal 2009; Reta 2010; Pieroni et al. 2014) and to fulfill need such as food, health, and culture (Tamalene et al. 2016). Ethnobotany helps people collect information on how communities traditionally use certain plants as medicinal plants, what diseases can be treated and how it can be done (Ford 1978). Ethnobotany helps to clarify the differences between how society utilizes forest products and preserves nature (Reid et al. 2009). This study, therefore, attempted to: (i) identify potential medicinal plants used by Dayak Desa community; (ii) describe the traditional knowledge of using the plants.

\section{MATERIALS AND METHODS}

\section{Time and location}

The study was conducted in June 2017. Ethnobotany survey was conducted in Pakak Village, Kayan Hilir Subdistrict, Sintang District, West Kalimantan Province, Indonesia.

\section{General condition of the research sites}

Pakak Village, Kayan Hilir Sub-district, Sintang District of West Kalimantan Province, Indonesia has an area of 320 squares kilometer (32.000 ha). Pakak Village has 5 hamlets consisting of Pakak 1, Pakak 2, Pakak 3, Pakak 4, and Pakak 5. There are about 1157 people and 293 households residing in this village. Pakak is bordered by Lalang Ingar Village in the west, Sungai Sintang Village in the north; Tertung Mau Village in the south, and Riam Panjang Kayan Hulu in the east. Pakak Village is located in a highland area surrounded by hilly areas. One of the hills that provide main resources for Pakak community is Bukit Bang (Pakak Village 2016). The map of Pakak Village is shown in Figure 1.

\section{Informants selection}

Informants were selected using snowball sampling method. Snowball sampling is used for collecting data obtained from the main source that can be branched into multiple sources of information (Bernard 2002). Informants were determined based on information from community leaders, tribal leaders, village heads, head of kampung (small village) and other reliable sources who know things that are closely related to the research. The number of informants consisted of 3 community leaders, one tribal leader, one head of the village, and one head of the kampung.

\section{Data collection}

Ethnobotany data were collected using structured interviews. The interviews were used to gather information on the local names, parts of the plants, benefits of the plants and how the plants are used (Martin 1995; Cunningham 2001).
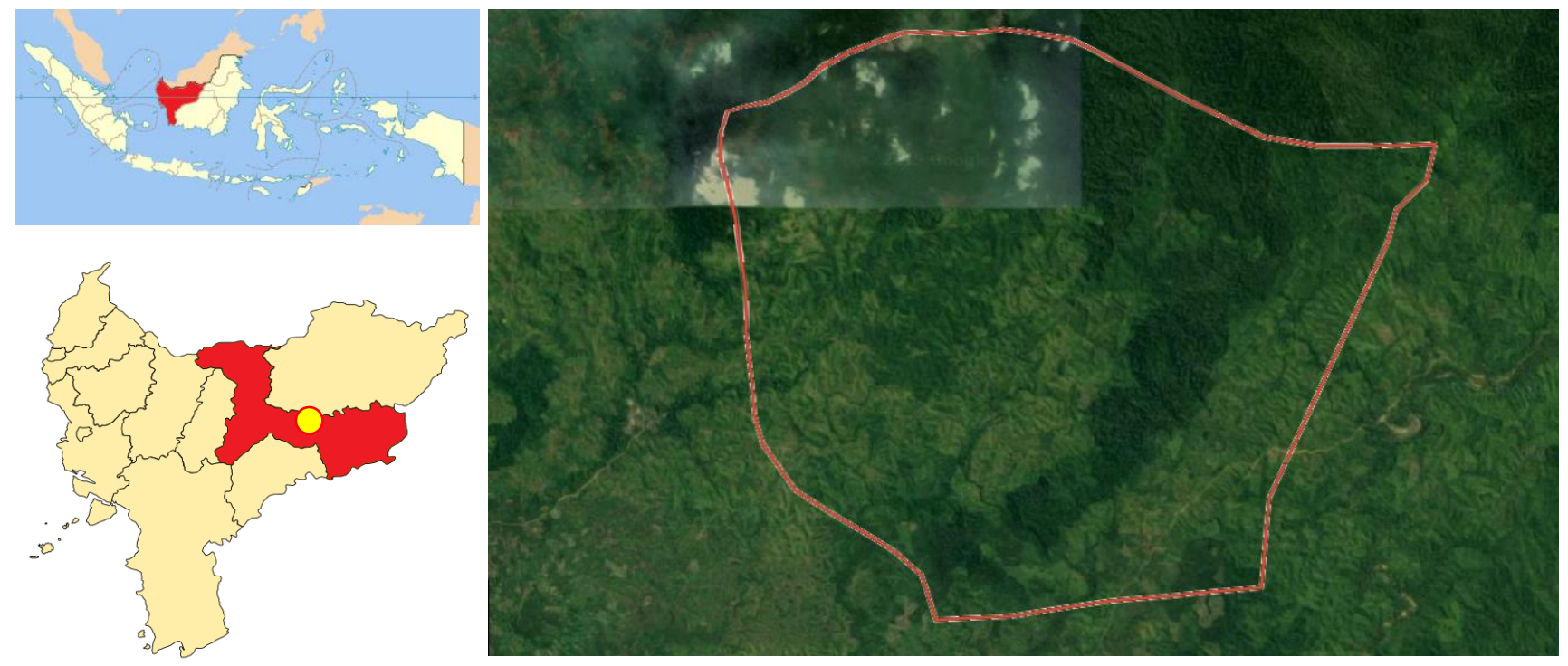

Figure 1. Pakak Village Administrative Area, Kayan Hilir Sub-district, Sintang District, West Kalimantan Province, Indonesia 
Table 1. Number of Species (with ICS Values)

\begin{tabular}{ll}
\hline ICS values & Category \\
\hline (ICS 100 and over) & Very High Significance \\
(ICS 50-99) & High Significance \\
(ICS 20-49) & Moderate Significance \\
(ICS 5-19) & Low Significance \\
(ICS 1-4) & Very Low Significance \\
$($ ICS 0) & Negligible Significance \\
\hline
\end{tabular}

\section{Data analysis}

Data analysis followed four concurrent activities: data collection, data reduction, data presentation, and conclusion drawing. The collected data were analyzed descriptively and presented in the form of tables and graphs. Quantitative data analysis used Index of Cultural Significance (ICS) suggested by Turner (1998). ICS calculations aimed to identify the most important plant species in people's lives (Ajiningrum 2011). The calculations employed the following formula:

$$
\operatorname{ICS} \sum_{i=1}^{n}(q x i x e) u_{\mathrm{i}}
$$

Where:

$$
\begin{array}{ll}
\text { ICS } & \text { : Index of Cultural Significance } \\
\mathrm{Q} & \text { : Quality value } \\
\mathrm{I} & \text { : Intensity value } \\
\mathrm{E} & \text { : Exclusivity value }
\end{array}
$$

The results, then, were categorized based on the ICS value proposed by Turner (1998) such as shown in Table 1.

\section{RESULTS AND DISCUSSION}

\section{Types of plants used as medicinal plants}

The results of the interviews conducted with some informants from Dayak Desa community suggested that there were 25 species of medicinal plants used by the community as traditional medicine. These plant species are presented in Table 2.

Dayak Desa community utilizes medicinal plants based on traditional knowledge passed down from generation to generation. Medicinal plants are used as the first alternative step to treat diseases. The cultivated or wild plants are taken directly from the forest or home yard. Species from Araceae family dominate the medicinal plants used by Dayak Desa community. The percentage of the medicinal plant families used by the community is depicted in Figure 2 .

Dayak Desa community makes use of plants root, tuber, rhizome, stem, bark, leaves, flowers, fruit and even all parts of the plants as medicine. The most widely used part is the leaves $(48 \%)$. The percentage of plant parts used as traditional medicine by Dayak Desa community is presented in Figure 3.

Dayak Desa community does different things on the medicinal plants. They sometimes boil and drink the extract, or pound and smear a certain part of the plants. In addition to that, they also use a part of the plant for bathing or just rub it to the body, and many others. However, the most popular ways to apply are to boil and drink the extract, or just pound and smear a part of the plants (32\%). Meanwhile, the least popular ways to apply are using the plants for bathing, heating, and pasting, boiling and eating, crushing and drinking, pounding, boiling and drinking (4\% of each). The information on how the people process medicine is summarized in Figure 4.

\section{Index of cultural significance of useful plants (ICS)}

The estimation of ICS value of 25 species of medicinal plants used by Dayak Desa community ranged from 1 to 24 (Table 3). The results of data analysis based on ICS value proposed by Turner (1998) are presented in Figure 5.

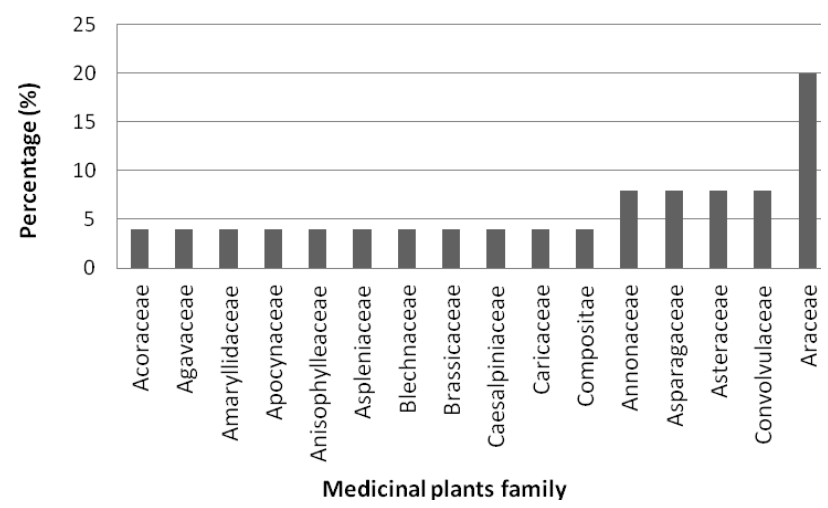

Figure 2. Medicinal plants family used by Dayak Desa community

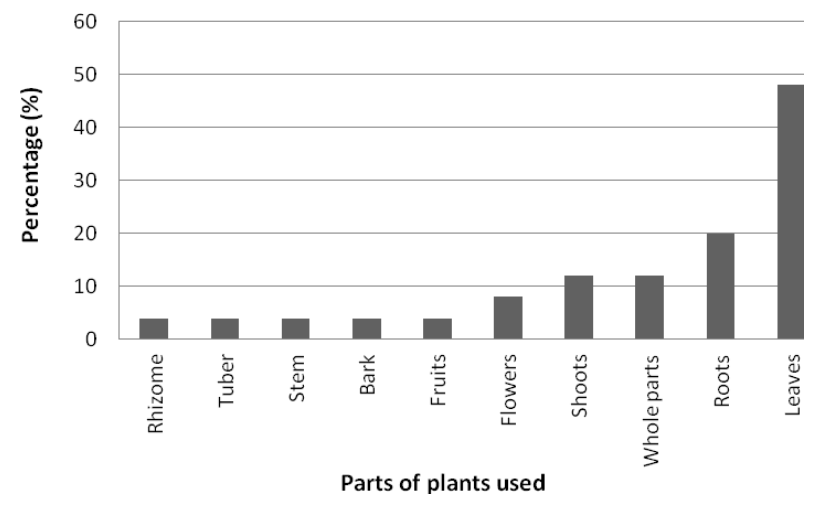

Figure 3. Parts of plants used as medicine

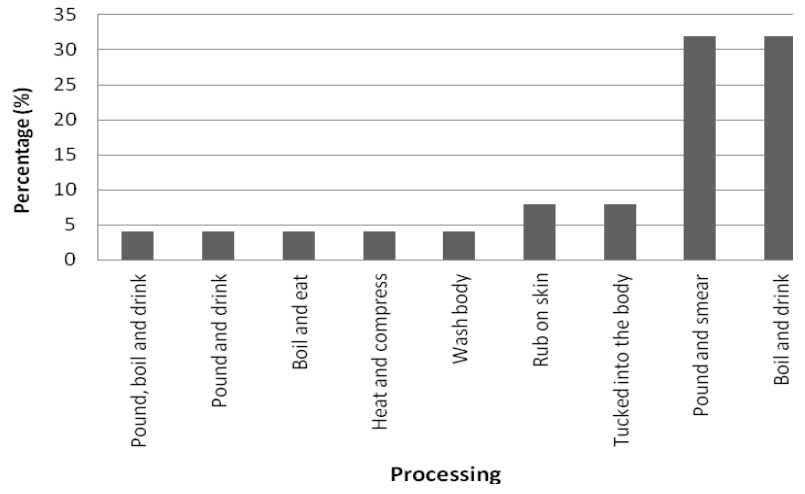

Figure 4. Medicinal plants processing 
Table 2. Lists of species of medicinal plants used by Dayak Desa community

\begin{tabular}{|c|c|c|c|c|c|}
\hline Local name & Scientific name & Family & Plant part & Procedure & Use \\
\hline Jerangau & Acorus calamus $\mathrm{L}$. & Acoraceae & Rhizome, stem & Pound, smear & A cough \\
\hline Sabang & Parthenocissus quinquefolia (L.) Planch & Agavaceae & Shoots & Pound, smear & Pain in the ribs area \\
\hline Bakung & Crinum asiaticum $\mathrm{L}$. & Amaryllidaceae & Tubers & Pound, smear & Orchitis \\
\hline Kayu ribu & Anisophyllea disticha (Jack) Baill. & Anisophylleaceae & Root & Boil in water, drink & Fatty liver \\
\hline Nangka Belanda & Annona muricata (L.), cv.Elita & Annonaceae & Leaf & Boil in water, drink & High blood pressure and gout \\
\hline Kayu kenanga & Canangium odoratum Baill & Annonaceae & Roots, leaf, bark & Tuck into the body & Used for battle \\
\hline Pelaik & Alstonia scholaris L. & Apocynaceae & Whole plant & Pound, smear/ drink & Internal wounds (contusion) from falling \\
\hline Buruk sisi & Arisaema tortuosum (Wall) Schott & Araceae & Leaf & Boil in water, drink & A headache \\
\hline Ilung & Homalomena occulta (Lour) Schott & Araceae & Whole plant & Pound, smear & Burnt \\
\hline Keladi & Colocasia esculenta $\mathrm{L}$. & Araceae & Whole plant & Boil in water, eat & High Blood pressure \\
\hline Pinang & Areca catechu $\mathrm{L}$. & Arecaceae & Fruit & Pound, smear & Ulceration \\
\hline Pusuh kelapa & Cocos nucifera $\mathrm{L}$. & Arecaceae & Flower & Boil, drink & Maintain breast milk supply \\
\hline Sabang balek & Cordyline fruticosa $\mathrm{L}$. & Asparagaceae & Leaf & $\begin{array}{l}\text { Tuck into the body (element of } \\
\text { magic) }\end{array}$ & An antidote to thepoison \\
\hline Telusuh punan & Dracaena marginata Lam. "tricolor" & Asparagaceae & Root & Boil, drink & Childbirth \\
\hline Rajang & Asplenium nidus $\mathrm{L}$. & Aspleniaceae & Shoots & Pound, smear & Ulcers \\
\hline Sawi hantu & Elephantopus scaber L. & Asteraceae & Leaf & Pound, mix with water, drink & Fever (malaria) \\
\hline Kayu alit & Ageratum conyzoides $\mathrm{L}$. & Asteraceae & Root, leaf & Pound, boil in water, drink & Wound \\
\hline Pakis miding & Stenochlaena palustris (Burm) Bedd & Blechnaceae & Root & Boil in water, drink & Internal wounds and erection problem (man) \\
\hline Inai anan & Cardamine hirsuta $\mathrm{L}$. & Brassicaceae & Leaf, flower & Rub on the skin & Wash body \\
\hline Gelinggang & Cassia alata Linn & Caesalpiniaceae & Leaf & Pound, smear & Ringworm \\
\hline Pepaya & Carica papaya $\mathrm{L}$. & Caricaceae & Leaf & Boil in water, drink & $\begin{array}{l}\text { fever, intestinal worms, toothache and } \\
\text { headache }\end{array}$ \\
\hline Mambung & Blumea balsamifera D.C & Compositae & Leaf & Heat, compress & Fever \\
\hline Akar jelayan & Merremia peltata (L.) Merrill & Convolvulaceae & Shoots & Pound, smear on the bitten part & A venomous animal bite \\
\hline Ampur & Argyreia nervosa (Burm. F.) Bojer & Convolvulaceae & Leaf & Rub on the skin & Refine the skin \\
\hline Pentawar & Cheilocostus speciosus (J.Koenig) C. Specht & Costaceae & Leaf & Wash body & Stamina refresher or enhancer \\
\hline
\end{tabular}


Table 3. The ICS value of the medicinal plants

\begin{tabular}{|c|c|c|c|c|c|}
\hline Scientific name & $\mathbf{Q}$ & $\mathbf{I}$ & $\mathbf{E}$ & Total ICS & Category \\
\hline Acorus calamus L. & 3 & 3 & 2 & 18 & Low Significance \\
\hline Parthenocissus quinquefolia (L.) Planch & 3 & 3 & 1 & 9 & Low Significance \\
\hline Crinum asiaticum $\mathrm{L}$. & 3 & 2 & 0.5 & 3 & Very Low Significance \\
\hline Anisophyllea disticha (Jack) Baillon & 3 & 2 & 1 & 6 & Low Significance \\
\hline Annona muricata (L.), cv. Elita & 3 & 3 & 2 & 18 & Low Significance \\
\hline Canangium odoratum Baill & 2 & 1 & 0.5 & 1 & Very Low Significance \\
\hline Alstonia scholaris L. & 3 & 2 & 1 & 6 & Low Significance \\
\hline Arisaema tortuosum (Wall) Schott & 3 & 3 & 1 & 9 & Low Significance \\
\hline Homalomena occulta (Lour) Schott & 3 & 2 & 0.5 & 3 & Very Low Significance \\
\hline Colocasia esculenta L. & 3 & 4 & 2 & 24 & Moderate Significance \\
\hline Areca catechu $\mathrm{L}$. & 3 & 3 & 0.5 & 4,5 & Very Low Significance \\
\hline Cocos nucifera $\mathrm{L}$. & 3 & 5 & 1 & 15 & Low Significance \\
\hline Cordyline fruticosa $\mathrm{L}$. & 3 & 3 & 1 & 9 & Low Significance \\
\hline Dracaena marginata Lam. "tricolor" & 3 & 3 & 1 & 9 & Low Significance \\
\hline Asplenium nidus $\mathrm{L}$. & 3 & 2 & 1 & 6 & Low Significance \\
\hline Elephantopus scaber L. & 3 & 3 & 1 & 9 & Low Significance \\
\hline Ageratum conyzoides $\mathrm{L}$. & 3 & 2 & 1 & 6 & Low Significance \\
\hline Stenochlaena palustris (Burm) Bedd & 3 & 3 & 1 & 9 & Low Significance \\
\hline Cardamine hirsuta L. & 3 & 2 & 0.5 & 3 & Very Low Significance \\
\hline Cassia alata Linn & 3 & 3 & 2 & 18 & Low Significance \\
\hline Carica papaya $\mathrm{L}$. & 3 & 4 & 1 & 12 & Low Significance \\
\hline Blumea balsamifera D. C & 3 & 3 & 1 & 9 & Low Significance \\
\hline Merremia peltata (L.) Merrill & 3 & 3 & 2 & 18 & Low Significance \\
\hline Argyreia nervosa (Burm. f.) Bojer & 3 & 2 & 0.5 & 3 & Very Low Significance \\
\hline Cheilocostus speciosus (J. Koenig) C. Specht & 3 & 2 & 1 & 6 & Low Significance \\
\hline
\end{tabular}

Note: Q: Quality Value, I: Intensity value, E: Exclusivity value, ICS: Index of Cultural Significance (Index of Cultural Significance)

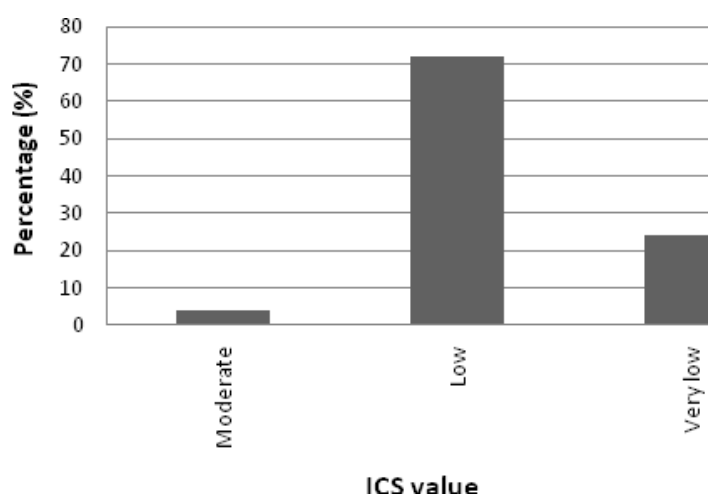

Figure 5. The percentage of the medicinal plants ICS value

\section{Discussion}

For Dayak Desa community in Pakak Village, forests are part of their life. Forests are places where they can find resources to fulfill their daily needs. Not only forests, some other landscapes such as fields, settlements and former fields are also used to support the community life. Communities which constantly interact with the surrounding environment tend to have deep local knowledge related to the surrounding resources (Gadgil et al. 1993). People who are often faced with many challenges possess more local knowledge compared to other community groups who are rarely confronted with critical times (Berkes and Folke 1998). In everyday life, local people cannot be separated from their natural environment, especially plants. Plants have many benefits, such as for food, shelter, clothing, medicine and so on. Plants also contribute indirectly to people's life. Plants that are considered sacred or magical are generally used in traditional ceremonies or rituals and social activities of local communities.

The traditional knowledge possessed by the community is influenced by their culture, environmental conditions, cultural transformation, technological intervention and interaction among people in the community. People with a higher level of culture will be able to manage plants diversity and utilize them optimally. On the contrary, people with a lower cultural level will manage the plants based on their need to fulfill their life.

We are still unable to predict when humans start to make use of plants to fulfill their needs (Purwanto and Walujo 1995). However, it can be assumed that a desire to try and taste the plants is the beginning of everything. The attractiveness of the plants is sourced from their color, taste, appearance, flowers, and, if there is any, fruits. People think that these properties of plants can benefit them; thus, they attempt to seek, collect, grow, and cultivate the plants.

The results of the survey and interviews conducted to some informants from Dayak Desa community showed that there were 25 species of medicinal plants used by the community. The plants are usually collected from the areas around where they live: Menuah forest and Bukit Bang 
area. The knowledge of the use of the plants as medicine is obtained from parents, community members, and ancestors who come to them in dreams. This knowledge is delivered orally only to the people who are believed to be able to live the spirit through customary rituals.

The results of the interviews also revealed 9 families of plants from which 25 species come from. Mostly, people use plants from Araceae family. Plants from Araceae family is not only used as efficacious drugs but also as an ornamental plant (Sriasih et al. 2015). Plants from Araceae family is often used as medicine because they contain bioactive compounds (Cotton 1996). Dayak Desa also uses plants from other families including Asteraceae, Annonaceae, Caesalpiniaceae, Blechnaceae, Anisophylleaceae, Amaryllidaceae, and Acoraceae.

Plants generally consist of roots, stems, leaves, flowers, fruits, and seeds. Plant parts often used for the treatment of ailments are leaves, bark, stem, fruit, and root or tubers (Putri et al. 2016). The results of the present research showed that most of the people in the community usually use the leaf $(48 \%)$, root $(20 \%)$, all plant parts $(12 \%)$, shoots $(12 \%)$, flowers $(8 \%)$, fruits $(4 \%)$, bark $(4 \%)$, stems $(4 \%)$, tubers $(4 \%)$ and rhizomes $(4 \%)$. Dayak Desa community believes that they will not kill the plants if they only use the leaves because the leaves will grow back and can be used continuously (Zuhud and Haryanto 1994). Therefore, they start to reduce the use of other parts of the plants such as stems, roots, rhizomes, tubers, and bark as medicine because it can kill these plants if they are used continuously (Swason 1998).

The high frequency of the use of leaves as a medicinal agent (48\%) appears to be associated with several advantages such as greater number or productivity of leaves, easier to obtain than other parts and relatively easy to use because they can be used directly (Hamzari 2008; Handayani 2015). Also, leaves are one important part of a plant because the process of photosynthesis occurs in the leaves so that nutrients that become medicinal properties are found in the leaves.

Prior to the use, some parts of the medicinal plants need to be processed. Some people even boil the plants before consuming them. Some others just pound the plants using a certain tool and apply it to the sick body. Processing by tucked into body means medicinal plants inserted in certain body parts, such as tuck on the ear (as a magical element). Processing by rubbing means the medicinal plants rubbed on the sick body. Processing by using for bathing means medicinal plants put in water and used for bathing. Processing by heating means medicinal plants are heated in the embers and then affixed to certain body parts. Processing by pounding and drinking means the pounded medicinal plants are mixed with water. Pounding, boiling and drinking process means medicinal plants are crushed, and then boiled in water to be drunk.

Most of the people do boiling and drinking process (32\%) and pounding and smearing (32\%). Processing by boiling is commonly used because it is easy to do.
Processing by pounding is also easy to do. Other uses include tuck on body parts $(8 \%)$, rub on the skin $(8 \%)$, wash body (4\%), heat and compress $(4 \%)$, boil and eat $(4 \%)$, pound and drink (4\%), and pound, boil, and drink (4\%). Boiling and drinking process has the highest percentage because Dayak Desa community believes that in the process of boiling, essence can be produced and of course, easily absorbed by the body. Dayak Desa community will apply pounding and smearing process to external diseases and boiling and drinking process to internal diseases.

The results of the interview were later analyzed using Index Cultural Significance (ICS). It is a quantitative ethnobotany analysis showing the importance of each species of useful plant based on the needs of the community (Munawaroh et al. 2011). The variety of useful plants within a community group determines its importance to be preserved by the local community. Plants that have more varied uses will be often used by the community so that people will tend to keep their availability in nature.

The estimated calculation of Index Cultural Significance (ICS) of medicinal plants used by Dayak Desa community in Pakak Village, Kayan Hilir Sub-district, Sintang District ranged from 1 to 24 . The lowest ICS value was possessed by kayu kenanga (Canangium odoratum Baill) and the highest ICS value was possessed by keladi (Colocasia esculenta L.) (ICS = 24). This type is widely used by the community, especially as a cure for high blood pressure. The intensity of keladi use is quite high and the exclusivity or favorite level of the plant is preferable. Plants that have more benefits will have greater ICS value, which means to be more valuable and more exclusive (Hager 2008). The community placed keladi at the highest level of the most useful and valuable plant because keladi can be used with high intensity as foodstuff and food ingredients. This finding indicates that Dayak Desa community interacts mostly with this species and it means that this species will continue to evolve along with the cultural development in Pakak Village.

Dayak Desa people invest certain philosophical meanings in using plants as traditional medicines. The plants that have philosophical meanings include: (i) kayu ribu (Anisophyllea disticha (Jack) Baillon), which is believed to have a thousand benefits; (ii) tapak liman (Elephantopus scaber L.), which is believed to be the main medicine for various types of diseases caused by ghosts; (iii) telusuh punan (Dracaena marginata Tricolor), which is believed provide protection when a mother gives birth; (iv) pentawar (Cheilocostus speciosus (J. Koenig) C. Specht), which has the meaning of being conditioning because the plants are cold; (v) akar jelayan (Merremia peltata (L.) Merrill), which is believed to repel or be an antidote to poison; (vi) pelaik (Alstonia scholaris L.) which is believed to be able to repair organs damaged by falls; (vii) sabang balek (Cordyline fruticosa L.), which is believed to restore all diseases that attack humans to nature. 


\section{ACKNOWLEDGEMENTS}

We would like to thank Ministry of Research, Technology, and Higher Education of the Republic of Indonesia through Directorate of Research and Community Services for fund assistance through contract number: 02/L-2/Penelitian.dikti/II/2018.We would like to thanks to (i) Chairman of the Education Agency of Karya Bangsa Sintang, (ii) Chairman of STKIP Persada Khatulistiwa Sintang, (iii) Dean of Faculty of Mathematics and Science of Universitas Negeri Malang, (iv) Pakak Village Chief, Customary Board, community leaders and all informants who have provided assistance related to all research activities conducted in Pakak Village, Kayan Hilir Subdistrict, Sintang District, West Kalimantan, Indonesia.

\section{REFERENCES}

Ajiningrum PS. 2011. Valuasi potensi keanekaragaman jenis hasil hutan nonkayu (HHNK) masyarakat lokal Dayak Lundayeh dan Uma'lung di Kabupaten Malinau Kalimantan Timur [Thesis]. Universitas Indonesia, Depok. [Indonesian]

Albuquerque UP, Lucens RFP, Monteiro JM, Florentino ATN and Almeida CF. 2006. Evaluating two quantitative ethnobotanical techniques. J Ethnobot Res Appl 4: 51-60.

Alexiades NM. 2003. Ethnobotany in the Third Millennium: expectation and unresolved issues. Delpinoa 45: 15-28.

Aryal PS. 2009. Ethnobotany of Tharu: Incorporation of Culture and Biodiversity Conservation (A case study of Jayanagar VDC of Kapilvastu District). [Thesis]. Tribhuvan University, Kathmandu, Nepal.

Balick MJ, Cox PA. 1996. Plants, People, and Culture: The Science of Ethnobotany. Scientific American Library, New York.

Bennett BC. 2005. Ethnobotany education, opportunities, and needs in the U.S. Ethnobot Res Appl 3: 113-121.

Berkes F, Folke C. 1998. Linking Social and Ecological System for Resilience and Sustainability. Cambridge University Press, Cambridge.

Bernard HR. 2002.Research methods in anthropology: Qualitative and quantitative approaches. 3rd ed. Alta Mira Press, Walnut Creek, CA.

Binford LR. 1962. Archaeology as Anthropology. Amer Antiquit 28: 217 225 .

Choudhary K, Singh M, Pillai U. 2008. Ethnobotanical Survey of Rajasthan-An Update. Amer-Eur J Bot 1 (2): 38-45.

Cotton CM. 1996. Ethnobotany Principles and Application. John Wiley and Sons Ltd. Baffin Lane, Chichester, UK

Cunningham BA. 2001. Applied Ethnobotany People, Wild Plant Use, and Conservation. Earthscan Publications Ltd., London.

Darmono. 2007. Kajian Etnobotani Tumbuhan Jalukap (Centella asiatica L.) di Suku Dayak Bukit Desa Haratai 1 Laksado. Program Studi Pendidikan FKIP Universitas Lambumg Mangkurat, Banjarmasin. [Indonesian]

Ford IR. 1978. Ethnobotany: Historical diversity and synthesis In: The Nature and status of Ethnobotany. Anthropogenic papers. Museum of Anthropology, University of Michigan, Ann Arbor, Michigan.

Gadgil MF, Berkes F, Folke C. 1993. Indigenous knowledge for biodiversity conservation. Ambio 22 (2-3): 151-156.

Hager TF. 2008. Processing and storage effects on monomeric anthocyanins, percent polymeric color, and antioxidant capacity of processed blackberry products. J Agric Food Chem 56: 689-695.

Hamzari. 2008. Identifikasi tanaman obat-obatan yang dimanfaatkan oleh masyarakat sekitar hutan Tabo-tabo. Jurnal Hutan dan Masyarakat 3 (2): 111-234. [Indonesian]

Handayani A. 2015. Utilization of medical plants by people around Gunung Simpang Nature Reserve, West Java. Pros Sem Nas Masy Biodiv Indon 1 (6): 1425-1432. [Indonesian]

Julung H, Supiandi MI, Ege B, Mahanal S, Zubaidah S. 2018. Analisis Sumber Pengetahuan Tradisional Tanaman Obat yang Digunakan oleh Masyarakat Suku Dayak Desa. Proceeding of Biology Education 2 (1): 67-74. [Indonesian]

Kaido TL, Veale DJH, Havlik I, Rama DBK. 1997. Preliminary screening of plantsused in South Africa as traditional herbal remedies during pregnancy and labour. J Ethnopharmacol 55: 185-191.

Kustiawan W. 2007. Medicinal plants of Kalimantan forest: A review. Natural Life 2 (1): 24-34.

Martin GJ. 1995. Ethnobotany: A Methods Manual. Chapman and Hall, London.

Mesfin K, Tekle G, Tesfay T. 2013. Ethnobotanical study of traditional medicinal plants used by indigenous people of Gemad District, Northern Ethiopia. J Med Plants Stud 1 (4): 32-37.

Munawaroh E, Saparita R, Purwanto Y. 2011. Ketergantungan masyarakat pada hasil hutan non kayu di Malinau, Kalimantan Timur: suatu analisis etnobotani dan implikasinya bagi konservasi hutan. Berk Penel Hayati Edisi Khusus 7A: 51-58.

Pakak Village. 2016. Pakak Village in Figures 2016. Sintang, West Kalimantan. [Indonesian]

Pie S, Xiu J. 2002. Applied ethnobotany: Participatory approach for community development and conservation. Chinese J Ecol 21 (6):4046.

Pieroni A, Anely N, Avni H, Mustafa B, Bruno S, Kevin C, Cassandra LQ. 2014. Local knowledge on plant and domestic remedies in the mountain village of Peshkopia (Eastern Albania). J Mt Sci 11 (1): 180-194.

Purwanto Y, Walujo EB. 1995. Keanekaragaman Sumber Daya Tumbuhan Bahan Pangan Masyarakat Dani, Irian Jaya dan Perspektif Pelestariannya. Prosiding Seminar dan Lokakarya Nasional Etnobotani II. IPI. Jakarta. [Indonesian]

Putri LSE, Dasumiati, Kristiyanto, Mardiansyah, Malik C, Leuvinadrie LP, Mulyono EA. 2016. Ethnobotanical study of herbal medicine in Ranggawulung Urban Forest, Subang District, West Java, Indonesia. Biodiversitas 17 (1): 172-176.

Reid S, Wishingrad V, McCabe S. 2009. Plant Uses: California Native American Uses of California Plants Ethnobotany. UC Santa Cruz Arboretum. California.

Reta H. 2010. An Ethnobotanical Study of Useful Plants of the Farming Site In Gozamen Mereda, East Gojjam Zone of Amhara Region, Ethiopia. Addis Ababa University, Ethiopia.

Roslinda E. 2016. Dayak Desa forest land use system as social capital to acquire forest management rights in West Kalimantan, Indonesia. Biodiversitas 17 (1): 177-184

Setyawan AD. 2010. Review: Biodiversity conservation strategy in a native perspective; case study of shifting cultivation at the Dayaks of Kalimantan. Nusantara Biosci 2 (2): 97-108

Sriasih N, Warseno T, Kurniawan A. 2015. Studi Invetarisasi Araceae di Gunung Seraya (Lempuyang), Karangasem, Bali. Pros Semnas Masy Biodiv Indon 1 (3): 521-527.

Swason JK. 1998. Antibiotic resistence of Propionibacterium acnes in Acne vulgaris. Dermatol Nurs 15 (4): 369-362.

Takoy DM, Linda R, Lovadi I. 2013. Tumbuhan berkhasiat obat Suku Dayak Seberuang di kawasan hutan Desa Ensabang Kecamatan Sepauk, Kabupaten Sintang. Protobiont 2 (3): 122-128.

Tamalene MN, Al Mudhar MHI, Suarsini E, Rahman F, Hasan S. 2016. Ethnobotany of Canarium plant species used by Tobelo Dalam (Togutil) ethnic community of Halmahera Island, Indonesia. Biodiversitas 17 (1): 61-69.

Tesfaye H, Sebsibe D, Zemede. 2009. An ethnobotanical study of medicinal plants used by local people in the lowlands of Konta Special Wereda, Sothern Nations, Nationalities and People Regional State, Ethiopia. J Ethnobiol Ethnomed 6: 25. DOI: 10.1186/17464269-5-26

Turner NJ. 1998. The importance of a rose: Evaluating the cultural significance of plants in Thompson and Lillooet Interior Salish. J Amer Anthropol 90: 272-290.

Yusro, Fathul, Yeni M, Farah D, Kazuhiro. 2014. Inventory of medicinal plants for fever used by four Dayak Sub Ethnic in West Kalimantan, Indonesia. Kuroshio Sci 8 (1): 33-38.

Zuhud EAM, Haryanto. 1994. Pelestraian Pemanfaatan Keanekaragaman Tumbuhan Obat Hutan Tropika Indonesia, Fakultas Kehutanan, Institut Pertanian Bogor dan Lembaga Alam Tropika, Bogor. [Indonesian] 